BJHS: Themes 1: 43-59, 2016. C British Society for the History of Science 2016. This is an Open Access article, distributed under the terms of the Creative Commons Attribution-NonCommercialNoDerivatives licence (http://creativecommons.org/licenses/by-nc-nd/4.0/), which permits noncommercial re-use, distribution, and reproduction in any medium, provided the original work is unaltered and is properly cited. The written permission of Cambridge University Press must be obtained for commercial re-use or in order to create a derivative work.

doi:10.1017/bjt.2016.6 First published online 28 March 2016

\title{
Negotiating natural history in transitional China and British India
}

\author{
FA-TI FAN* AND JOHN MATHEW **
}

\begin{abstract}
This article examines scientific developments in China and India by comparing and contrasting the enterprises of natural history during the late nineteenth and early twentieth centuries. From this perspective, the cases of China and India shared some similarities, but also exhibited important differences with respect to the conditions, ideologies, personnel, processes and strategies in scientific development. Two very large countries, with much left unexplored, attracted broad scientific interest in their flora and fauna from the early modern period; the interest intensified in the nineteenth century because of increasing accessibility to their interiors. However, the different historical situations that involved empire, nation, professionalization, geography and domestic and international politics helped shape the respective trajectories of scientific development in the two countries. Yet, despite their differences, China and India shared important similarities in the co-production of science and state, the global hierarchy of knowledge production, and the coloniality of power relations. This historical complexity also represented an important aspect of the global history of science, one that still bears poignancy and resonance in the contemporary world.
\end{abstract}

This paper seeks to examine scientific developments in China and India through comparisons and contrasts of the prosecution of natural history during the late nineteenth and early twentieth centuries, a period well beyond the excesses and tragedies of the Opium Wars that fatally linked Qing China and British India during the mid-nineteenth century. While the larger pursuit of scientific endeavour forms its contextual backdrop, we employ studies in natural history as exemplary of significant shifts in our understanding of how each country, one in transition from a monarchy to a republic, the other the decided jewel in another empire's crown, could still have common elements in forging their own identities as sites for the production of knowledge.

The history of natural history from the Age of Discovery has been inseparable from the history of imperialism. The British Empire extended its tentacles to far-flung places, collected information and objects of nature, transmitted them across different parts of the empire and beyond, and brought many of them home. The networks of empire were not composed of a centre and radiating spokes, as is often imagined; rather, they formed a

\footnotetext{
* History Department, State University of New York at Binghamton, PO Box 6000, Binghamton, NY 13902, United States. Email: ffan@binghamton.edu.

$* *$ Programme in the Humanities and Social Sciences, Indian Institute of Science Education and Research (IISER), Dr Homi Bhabha Road, Pashan, Pune 411008, Maharashtra, India.Email: john.mathew@iiserpune.ac.in.
} 
complex of criss-crossing flows and routes spanning much of the world. Nevertheless, Britain was flooded with new information and objects, and together they helped to transform the metropole. Conversely, the possession of such knowledge and data could be translated into power and authority. Whatever the concept used to capture the dynamics, be it moving metropolis, scientific imperialism/colonialism, participation of 'the natives', colonial modernity, contact zone, or circulation ${ }^{1}-$ the purpose is to historicize the process, highlight the complexity, and restore the agency of historical actors in the interdynamics among components of the geopolitics of power and the coloniality of knowledge production. From this perspective, the cases of China and India shared some similarities, but also exhibited important differences.

A key consideration in any such study is the unequal parsing of knowledge in the colonizer-colonized dyad, and while this article does not take for its remit a recounting of such theoretical concerns, it also does not ignore the fact that issues of the admittedly gate-kept circulation of information, the consequent mimicry of form, and the diffusion models of science are central elements of any discussion on the subject. Perhaps the signal point of comparison between China and India resides in temporality of influence. Seeing as India fell directly under British political influence after the Battle of Plassey in 1757, it was possible to start introducing centralizing studies first through statistical surveys and then region-wide institutionalized surveys by discipline, such as the Trigonometrical Survey, the Geological Survey, the Botanical Survey and the Zoological Survey. China, while never formally part of a European empire, was forcefully drawn into the spheres of Western imperialism at various times; the historical condition was necessarily affected, and the scientific discourse that attended such intersection in the 'contact zone', to use Mary Louise Pratt's term, and beyond it would result in comparable institutions in China of which India had been the recipient earlier. ${ }^{2}$ In both cases, there were European practitioners (if much more British in India than in China) but in terms of local influence, owing to differences in the colonial moment, China was able to involve and deploy far more native workers earlier in manners of influence and authority than was permissible to Indians until the final few decades of the Raj in South Asia.

1 See, for instance, George Basalla, 'The spread of Western science', Science (1967) 156, pp. 611-622. Roy Macleod, 'On visiting the "moving metropolis": reflections on the architecture of imperial science', Historical Records of Australian Science (1982) 5, pp. 1-16. Homi Bhabha, The Location of Culture, London: Routledge, 1994. Mary Louise Pratt, Imperial Eyes: Travel Writing and Transculturation, London: Routledge, 1992. Kapil Raj, Relocating Modern Science, London: Palgrave Macmillan, 2007; and Simon Schaffer, Lissa Roberts, Kapil Raj and James Delbourgo, The Brokered World: Go-betweens and Global Intelligence, 1770-1820, Sagamore Beach: Science History Publications, 2009. Fa-ti Fan, 'The global turn in the history of science', East Asian Science, Technology, and Society: An International Journal (2012) 6, pp. 249-258.

2 Fa-ti Fan, British Naturalists in China: Science, Empire, and Cultural Encounter, Cambridge, MA: Harvard University Press, 2004. Fan, 'Science in cultural borderlands: methodological reflections on the study of science, European imperialism, and cultural encounter', East Asian Science, Technology and Society: An International Journal (2007) 1, pp. 213-231. Erik Mueggler, The Paper Road: Archive and Experience in the Botanical Exploration of West China and Tibet, Berkeley: University of California Press, 2011. 


\section{Empire and nation}

Although Britain was the dominant foreign power in nineteenth-century China, it was by no means the only one. Imperial competition intensified as the century drew to a close. The foreign powers roughly divided China into several spheres of influence, prompting the United States to propose the Open Door Policy to ensure an equitable sharing of the Chinese market among the powers. Subsequently, there were important reshufflings of foreign influences in China, due to internal upheavals (for example, the Republican Revolution, 1911-1912) as well as international political events (including the Boxer Rebellion in 1900, the Russo-Japanese War of 1903-1904, the First World War and the Soviet Revolution). The prevailing condition of China at the time has been called semi-colonialism, sub-colonialism and hyper-colonialism. All of them - though with different degrees of emphasis - point to the fact that China was under the domination of more than one imperial power. Witnessing the situation, Sun Yat-sen lamented that China had to serve more than one master. During the Republican period, British influence waned, and Japan, the United States and the Soviet Union increasingly became important players in Chinese politics. ${ }^{3}$

Internally, Republican China was hardly a coherent nation state. Often there was more than one national government, and always there were regional powers. The Beijing parliamentary government changed hands dozens of times from 1912 to 1928 until the Guomindang forces defeated the rival powers, claimed the national government, and moved the capital to Nanjing. Not even then was China unified. Despite fragmented political authority, however, China managed to maintain a fair degree of political autonomy. The watchful balance of the foreign powers, despite their frequent meddling, left some breathing room to a country that was struggling to hold together and forge a nation state. China was a mosaic of native and foreign political presence and influence. There were pockets of foreign colonies and concessions, and broad spheres of influence carved out by the foreign powers, but there were also various Chinese regional governments or forces that competed with each other. ${ }^{4}$

But of course even when there was no formal imperialism or colonialism, the spectre of the coloniality of power lingered through the pattern of power differentials, which helped to shape the production and translation of scientific knowledge, institutions and materiality. Under these conditions, Chinese scientists needed to find a strategic approach in order to make themselves visible and relevant in the world of modern science.

Unlike in China, in India Britain was unarguably the driving force during the nineteenth century and the first half of the twentieth. If anything the jousting for political supremacy had occurred far earlier in the subcontinent, with a number of European powers jockeying for influence through the seventeenth century. By the middle of the

3 Ruth Rogaski, Hygienic Modernity: Meanings of Health and Disease in Treaty-Port China, Berkeley: University of California Press, 2004. William Summers, The Great Manchuria Plague of 1910-1911: The Geopolitics of an Epidemic Disease, New Haven, CT: Yale University Press, 2012.

4 Prasenjit Duara, Rescuing History of the Nation: Questioning Narratives of Modern China, Chicago: The University of Chicago Press, 1995. Peter Zarrow, After Empire: The Conceptual Transformation of the Chinese State, 1885-1924, Stanford, CA: Stanford University Press, 2012. 
eighteenth century, the Portuguese and Dutch had already been reduced to the role of insignificant players (the Danish resolutely stayed only a trading concern) and the major contest fell to the French and the British, the latter ultimately emerging victorious largely in lockstep with parallel elements of the conflict between the same antagonists in other parts of the world in what was the Seven Years War (1756-1763). The key feature of the commerce of the matter, however, was that the presence of the European powers was largely mediated at the time through private trading companies (if supported to differing extents by powerful figures in government, often with direct investment), and thus after British dominance was secured, possessions in India were administered under the aegis of the English East India Company up to 1857. The Indian Mutiny broke the back of the Company and all its possessions subsequently redounded to the British Crown, a situation that would last until 1947, and decolonization. In this context, large surveys were initiated and augmented, both from the former Company's capital in Calcutta and from the new imperial capital (from 1911) in Delhi, the site of the former centre of power under the Mughal dynasty (1526-1858).

\section{Professionalization and progress in political contexts}

If ever there was a period when teleology ruled, it was the nineteenth century. Facts were sought eagerly and collective efforts made to achieve Whiggish ends. Neither China nor India was immune, except that negotiations on the ground resulted in subsequently hybrid forms of knowledge production. In both countries, European encounters found considerable artistic and technological development with which their own scientific experience had to be squared, even as China and India found themselves caught in the vortex of modernization. In China, despite competition from the traditional literati, a whole slew of new professions emerged, including law, banking, engineering and medicine, apart from forays into the sciences. Before the emergence of professional scientists, there had been other practitioners of modern science, including translators of foreign science texts, science teachers at middle schools, and collectors and taxidermists who worked for foreign naturalists and increasingly for natural-history museums in major cities. In the first decade of the twentieth century, there was an influx of scientists who had studied in Japan, but soon there emerged an elite class of scientists whose training had typically been in Europe and the United States and who occupied positions of authority in China through the Republican period.

The first generation of such influential scientists included the geologists Ding Wenjiang and Weng Wenhao, the botanists Qian Chongshu and $\mathrm{Hu}$ Xiansu, the zoologist Bin Zhi and the geneticist Chen Zhen; they formed the core of a growing professional community and launched new generations of professional scientists in their respective fields. By the middle of the 1930s, they had helped train a new generation of professional scientists in their chosen fields, as departments of geology and biology were entrenching themselves in higher education. In the meantime, professional associations were formed, and research institutes established. Bin Zhi and $\mathrm{Hu}$ Xiansu were the leading lights in this constellation, and deemed the founders of the modern disciplines of zoology and botany in 
China. Bin, one of the co-founders of the Science Society of China as a student, later obtained bachelor and doctoral degrees at Cornell University, with further research at Philadelphia's Wistar Institute. Bin returned to China in 1921, taking up a position at the Southeast University (Dongnan Daxue) in Nanjing, where he collaborated with $\mathrm{Hu}$ Xiansu and the two of them started the first biology department at a Chinse university. Hu had also returned from the United States a few years earlier, having trained between 1912 and 1917 in forestry and botany at the University of California; he would go again briefly to the country to complete a $\mathrm{PhD}$ at Harvard University through its Arnold Arboretum before resuming his position at Dongnan in $1925 .{ }^{5}$ Bin and $\mathrm{Hu}$ were essentially discipline builders. Their eventual output in scientific research remained unexceptional, but they commanded respect among their colleagues because of their dedication and contributions as mentors and leaders. They found ways to promote and support field biology at a time when resources were scant and the fence between academe and politics was thin. ${ }^{6}$

One area of immediate interest in Republican China was in mapping the nation state. The reasons were straightforward - all modern nation states strive to assess, map, utilize and manage their natural resources, discovering them, cataloguing them, quantifying them, exploiting them when needed, and, when not, keeping them as reservoirs of national power. Chinese scientists were cognizant of the role of place in science and tried to capitalize on it. There were good reasons why China should develop the field sciences. The most immediate and utilitarian one was to locate and exploit natural resources. The economic importance of coal and minerals was clear to all. That was a major reason why geology was one of the first modern scientific disciplines to receive government support in twentieth-century China. For the Chinese scientists, there was another practical reason: the accessibility of research materials and sites which, if not right in their backyard, were hardly beyond reach. Even better, some field sciences did not require expensive equipment, advanced training and precise operations. Such research seemed well suited for a poor country that had just begun developing modern institutionalized science.

There was yet another fundamental reason. Chinese field scientists - botanists, zoologists and geologists - believed that China, a huge, largely unexplored country with a wide range of climates and geographical features, was pregnant with abundant opportunities for research. Such thinking was not wishful. They knew, particularly those who had studied abroad, that foreigners had long been interested in the natural history of China and had done their best to explore the country for more than a century. They were convinced that pursuing geological and biological surveys in China would produce results that were unique, place-related, and yet of interest to the

5 With the recruitment of the botanist Qian Chongshu and the geneticist Chen Zhen (a student of T.H. Morgan's), along with other very talented scholars to join Bin Zhi and Hu Xiansu, and in short order the establishment of the Biological Laboratory of the Science Society of China, Southeast University swiftly established itself as the hothouse of modern Chinese biology. See, for example, Laurence Schneider, Biology and Revolution in Twentieth-Century China, Lanham, MD: Rowman and Littlefield, 2005, pp. 33-63.

6 Fa-ti Fan, 'Redrawing the map: science in twentieth-century China', Isis (2007) 98, pp. 524-538. Hu Zonggang, Jingshen shengwu diaochasuo shigao, Jinan: Shangdong jiaoyu chubanshe, 2005. 
international scientific community. Field science could provide Chinese scientists with a coveted platform and podium, where they could compete with foreign scientists. They would be in a position to be productive, visible and authoritative on matters in science. ${ }^{7}$ When, in the early 1930 s, Wang Jingxi, a laboratory scientist with a $\mathrm{PhD}$ in physiological psychology from Johns Hopkins, criticized the state of Chinese biology, owing to his unhappiness with what he regarded as the dominance of and overemphasis on field biology, a branch of science he considered to be outdated in the West, Hu Xiansu drew upon the reasons stated above in his retort. ${ }^{8}$

During the Republican period, new government agencies were established (for example the Geological Survey of China); new educational institutions were founded (for example universities and museums); new research institutes and projects were advanced (for example Academia Sinica, the Fan Memorial Institute of Biology); new professional societies were formed (for example the Botanical Society, the Geological Society, the Zoological Society); and outreach venues multiplied (for example the Science Society, science magazines). On the one hand, all of these efforts helped to solidify, organize, promote and reproduce the interests of professional scientists. On the other hand, the stakes were much higher than professional interests, and many Chinese scientists sincerely and firmly believed in the slogan kexue jiuguo or 'science can save our nation'. They were convinced that they had the duty and responsibility of modernizing China; scientists like themselves were particularly well suited for the Herculean task. ${ }^{9}$

Just like the geological survey or social survey, the enterprise of biological survey was part of the desire to map the nation state. ${ }^{10}$ Chinese scientists wanted to 'know' the geobody of the nation, rendering it intelligible in scientific terms. Unlike the geological survey, there was no government agency to administer biological surveys. In this respect, biological surveys in Republican China were similar to social surveys; they were hardly coherent, comprehensive or systematic. Rather they were often local, piecemeal and contingent upon the availability of people, money and opportunity. No single central organization or coordinated programme conducted biological surveys. Nevertheless, it is undeniable that the founding of the Fan Memorial Institute of Biology in 1928 marked a crucial moment. The Fan Memorial Institute was modelled on the ideas of the United States Bureau of Biological Survey and the Wistar Institute. Bin Zhi and then $\mathrm{Hu}$ Xiansu were appointed the director of the Fan Memorial Institute. The institute would pursue important field projects and quickly established itself as a centre of field biology in China. ${ }^{11}$

7 Grace Yen Shen, Unearthing the Nation: Modern Geology and Nationalism in Republican China, Chicago: The University of Chicago Press, 2013, pp. 73-108. Shellen Wu, Empires of Coal: Fueling China's Entry into the Modern World Order, 1860-1920, Stanford, CA: Stanford University Press, 2015.

$8 \mathrm{Hu}$ Zonggang, Bugai yiwang de Hu Xiansu, Wuhan: Changsha wenyi chubanshe, 2005, pp. 74-76.

$9 \mathrm{Hu}$, op. cit. (6); Zuoyue Wang, 'Saving China through science: the Science Society of China, scientific nationalism, and civil society in Republican China', Isis (2002) 93, pp. 291-322.

10 Tong Lam, A Passion for Facts: Social Surveys and the Construction of the China Nation-State, 19001949, Berkeley: University of California Press, 2011.

$11 \mathrm{Hu}$, op. cit. (6). 
How, if at all, did such sentiments inhere in the professionalization of science (not least the field sciences) in China's western neighbour at the start of about the same time, the second decade of the twentieth century (or, as historians would put it, the close of the long nineteenth century)? The year the First World War broke out might have been an odd moment to launch a Science Congress, but such was indeed the case in India, if several months before the misadventure in Sarajevo that precipitated such a cataclysmic turn of events in Europe. However, 1914 was a perfectly reasonable time for a certain degree of stocktaking to be done in the subcontinent. ${ }^{12}$ The British Crown had held direct sway for fifty-six years over its Jewel in the Crown after taking charge from its predecessor in power, the English East India Company, marked significantly in 1911 by the announcement of the move of the imperial capital from Calcutta to Delhi, coincident with the visit of the king-emperor, George V of Great Britain, and his consort Mary. ${ }^{13}$ There had been a number of centralizing efforts even earlier. Various surveys had been birthed, such as the Geological Survey in 1851 and the Botanical Survey in 1890 . The census had come into being in 1871, an exercise repeated every ten years. The Imperial Gazetteer, seemingly taking its cue from the statistical surveys first tried out in Scotland by Sir John Sinclair and replicated during the early years of the nineteenth century in India, ${ }^{14}$ sought to 'know' India systematically and scientifically, and the introductory volume (1881) dealt meticulously with the

physical foundations of India, represented by its geology, meteorology, botany and zoology, through a survey of its human inhabitants, similarly compartmentalized into ethnology, language and religion, to conclude, as if the highest stage in this evolutionary stage, with the departments of the colonial administration (public health and the police). ${ }^{15}$

In this scenario, the Imperial Gazetteer represented 'the empire's view of science rather than the scientists' view of empire'. ${ }^{16}$ In such a casting, the native inhabitants were often apparently rendered objectified - the passive recipients of a colonial gaze. An extreme instance was the placement of live people on display in an ethnological congress held in the Central Provinces in 1868, emblematic of such display, 'observable in motion, as functioning objects'. ${ }^{17}$ Similarly, the staging of science through museums for what was perceived to be a gawking, largely illiterate public also served to draw a thick dividing line between colonial administrators and a native populace in subordination. ${ }^{18}$

12 See Macleod, op. cit. (1), p. 13: 'Arguably British recognition of Indian Independence began not with 1947 but with the first meeting in Calcutta of the Indian Science Congress in 1914'.

13 Ironically, the shift of capital and the symbolic visit of the king-emperor to India would antedate the fall of the last ruling dynasty in China by a single year.

14 John Sinclair, The Statistical Account of Scotland drawn up from the Communications of the Ministers of the Different Parishes, 21 vols., Edinburgh: William Creech, 1814.

15 David Arnold, The New Cambridge History of India: Science, Technology and Medicine in Colonial India, Cambridge: Cambridge University Press, 2000, p. 131.

16 Arnold, op. cit. (15), p. 132.

17 Gyan Prakash, Another Reason: Science and the Imagination of Modern India, Princeton, NJ: Princeton University Press, 1999, p. 28.

18 Prakash, op. cit. (17), p. 31. 
But the first Science Congress was no parroting of the themes above. If anything, such a stark dichotomy is something of a caricature - there was considerably more agency to be sought and indeed deployed within the indigenous population; indeed the first president of the Science Congress was Indian himself, Sir Ashutosh Mukherjee, a celebrated lawyer and, at the time, the vice chancellor of the University of Calcutta. There had indeed been a surge of nationalistic fervour admixed with a scientific temper. In 1869, the allopathic/homeopathic doctor and social reformer Mahendra Lal Sircar had founded the Indian Association for the Cultivation of Science; ${ }^{19}$ while in 1893 Prafulla Chandra Ray, fresh from a doctorate in chemistry from the University of Edinburgh (1887), had begun the Bengal Chemical and Pharmaceutical Works, in order to develop on a larger scale the local preparation of pharmaceutical products. ${ }^{20}$ Jagadish Chandra Bose had re-created Hertzian waves at even shorter wavelengths in his laboratory at Calcutta's Presidency College, and even beyond it through a dramatic public display at the town hall where the waves in question were employed to set off gunpowder and the ringing of a bell. ${ }^{21}$ At more organizational levels of benefaction, the Parsee industrialist Jamshedji Nusserwanji Tata left three million rupees' worth of property towards the founding of an Imperial Institute modelled on that in London; the eventual entity situated in Bangalore and founded in 1909 would be named the Indian Institute of Science. 22

It was in this climate of imperial centralizing tendency and nationalist response especially in the physical sciences that two European professors of chemistry, J.L. Simonsen of Canning College, Lucknow, and P.S. Macmahon of Presidency College, Madras, mooted the idea of the Science Congress, disappointed as they were by the lack of original research at the university level in India ${ }^{23}$ (the laudable efforts of Ray and Bose still being in an overall sense anomalous) as well as its seeming appropriation by the state through various services under its aegis. ${ }^{24}$ At least a third of the papers were read by Indians. However, these were mainly in the physical sciences (four out of seven in physics). The natural sciences saw scant native representation (one out of nine in zoology). What might account for this disparity?

Unlike the initiative that was shown in the physical and chemical sciences (as evidenced earlier), there were no commensurate efforts of major note among Indians in biology. Natural history had remained the bailiwick of long-residing European residents in the country (in the main British), many of who were as committed to their land of

19 Pratik Chakrabarti, Western Science in Modern India: Metropolitan Methods, Colonial Practices, New Delhi: Permanent Black, p. 150.

20 Dhruv Raina, 'Ray's Life and Experiences as a text on the history of science', in Santimay Chatterjee, M.K. Dasgupta and Amitabha Ghosh (eds.), Studies in History of Science, Calcutta: The Asiatic Society, 1997, pp. 25-42, 28.

21 Jon Agar, Science in the Twentieth Century and Beyond, Cambridge: Polity Press, 2012, p. 17.

22 Arnold, op. cit. (15), p. 161.

23 Colleges and universities began early - a case in point being Hindu College (later Presidency College) in 1818. With the mid-nineteenth-century origination of the Universities of Calcutta, Bombay and Madras, there was an effort to include a number of subjects across the board roughly equivalent to those found in Britain. Nonetheless disciplines like zoology still found short shrift until the dawn of the twentieth century.

24 Arnold, op. cit. (15), p. 132. 
domicile as to that of their ethnic heritage. If the French had been at the vanguard of natural-history explorations at the top of the nineteenth century in the subcontinent, as part of a centralizing collecte $d u$ monde that typified the exploratory voyages from that nation, ${ }^{25}$ they had been by mid-century largely overtaken by the British. The result was a series of compendia on both plants and animals. While Joseph Dalton Hooker, the keeper of the Gardens at Kew, would expend several years working on the Flora of British India (1875-1897), a considerable expansion on Flora Indica volumes 1 (1820) and 2 (1824), both posthumous publications resulting from the exertions of William Roxburgh, superintendent of the Calcutta Botanical Gardens, animals would receive treatment according to taxa - Albert Guenther's The Reptiles of British India (1864), Thomas Caverhill Jerdon's The Birds of India (1862-1864) and The Mammals of India (1867) and Francis Day's The Fishes of India (1878) all being celebrated tomes of the kind and precursors to the ambitious Fauna of British India series whose publication under several editors (beginning with William Thomas Blanford) from 1888 to 1949 would see eighty-one volumes (plus one half-volume) penned by thirty-three authors, detailing taxonomically all of the known animal life of the region, from the Protozoa to the Mammalia. ${ }^{26}$ Alongside the early taxonomic works were those in natural history from an ecological and behavioural perspective, particularly by Brian Houghton Hodgson, resident in Nepal; Edward Blyth, the first paid curator of the museum of the Asiatic Society of Bengal (often described as the father of zoology in India); and Allan Octavian Hume, agricultural secretary to the government of India and a keen ornithologist. Many of the publications on natural history would find place in the journals emanating from the Asiatic Society of Bengal, a savant body founded in Calcutta in 1784 at the urging of a junior or puisne judge and polymath, Sir William Jones, where the topics under consideration were essentially those taken by the Imperial Gazetteer for its remit a century later. The Calcutta-based endeavour was joined in a couple of decades by literary societies (which, despite the name, also prosecuted the study of a wide variety of subjects including the scientific) in Bombay and Madras. The first journal exclusively given over to matters of natural history was the short-lived Calcutta Journal of Natural History, founded by John M'Clelland in 1841 and ceasing publication in 1848. Among the most significant bodies to emerge on the subject was, in 1886, the still extant Bombay Natural History Society.

Yet Indians, apart from serving as seasoned collectors, trackers and draughtsmen, were strangely absent from this enterprise. While from 1836 onward, following the first dissection by a native worker, Madhusudhan Gupta, of a human corpse in India

25 Marie-Noelle Bourguet, 'La collecte du monde: voyage et histoire naturelle (fin XVIIème siècle-début XIXème siècle)', in C. Blanckaert, C. Cohen, P. Corsi and J.-L. Fischer (eds.), Le muséum au premier siècle de son histoire, Paris, Editions du Muséum national d'histoire naturelle, 1997, pp. 163-196.

26 An intriguing paper, written by a native Indian, drew attention to the genesis of the Fauna in glowing terms: 'Indian zoologists, of all shades and capacities whatsoever, cannot be sufficiently grateful to the learned and disinterested British Memorialists for the mightily encouraging stimulus they have ... given to the further progress of Indian zoology. May the bright beaming torches they have lighted ... show us the bright-beaming light we have hitherto wanted! This light comes from West to East.' See K.R. Kirtikar, 'Progress in natural history during the last century', Journal of the Bombay Branch of the Royal Asiatic Society, extra number, the Centenary Memorial Volume, Bombay: Asiatic Society's Library, pp. 353-381, 353. 
at the newly founded Medical College and suitably celebrated by a gun salute, ${ }^{27}$ Indians were increasingly entering the ranks of medical men, there was no concomitant augmentation in numbers for natural history. In fact one of the candidates sent to London to study medicine, Soorjo Coomar Goodeve Chuckerbutty, won the gold medal for comparative anatomy at University College London and was trained by a former teacher of Charles Darwin, Robert Edmond Grant (1793-1874), who had been named to the first chair in zoology anywhere in England. Notwithstanding such illustrious tutelage and great exposure, Chuckerbutty, who would become the first native covenanted member of the Indian Medical Service, ${ }^{28}$ did not prosecute studies in natural history to any great extent upon his return to India to become professor of materia medica at the Calcutta Medical College. Other signal examples were hard to come by. One preponderant reason appeared to be race. The Geological Survey's Henry Benedict Medlicott (1829-1905) had remarked in 1880, in his statement of opposition to the appointment of Pramatha Nath Bose, that he was 'a Bengali and may be physically unfit for our work'.29

Allied apprehensions on the quality of the candidate on no other seeming basis but ethnic origin would delay the appointment of Ram Brahmo Sanyal to the superintendence of the Calcutta Zoological Garden in 1875, and it was only after a suitable candidate could not be found that the administrators of the Asiatic Society of Bengal and the decade-old Indian Museum consented to his elevation to a position that he would occupy with great distinction. Yet Sanyal's story was hardly unique in its reflection of quixotic patriarchal colonialism. It would be played out in more spheres of the enterprise of natural history, in zoology itself as well as in geology. Leviton and Aldrich draw especial reference to the fact that the Geological Survey of India initiated the practice of incorporating native talent into its ranks, starting with Thomas Oldham, who hired the natives Ram Singh, Kishen Singh and Hira Lal in 1874, the latter two also assigned to classes in the physical sciences at Calcutta's Presidency College. The authors point out that these hirings would result in the Indianization of the survey, which, at the time of Indian independence in 1947, would, along with the Zoological Survey of India (established in 1916), be predominantly staffed by native officers rather than colonial ones. ${ }^{30}$ Yet there would be resistance to appointing native workers to top administrative positions and this may have been a major reason why takers on the part of the indigenous population remained few. ${ }^{31}$ As P.C. Ray pointed out in his presidential address to the Seventh

27 Prakash, op. cit. (17), p. 123.

28 P.C. Sen Gupta, 'Soorjo Coomar Goodeve Chuckerbutty: the first Indian contributor to modern medical science', Medical History (1970) 14, pp. 183-191.

29 NAI/Home/Revenue, Agriculture, Surveys, Nos 44-47, May 1880 (Series B). Quoted in Deepak Kumar, Science and the Raj, New Delhi: Oxford University Press, 1995, p. 215.

30 A.E. Leviton and M.L. Aldrich, 'India: a case study of natural history in a colonial setting', in M.T. Ghiselin and A.E. Leviton (eds.), Cultures and Institutions of Natural History: Essays in the History and Philosophy of Science, San Francisco: California Academy of Sciences, 2000, pp. 51-80, 69.

31 See Deepak Kumar, 'Racial discrimination and science in nineteenth-century India', Indian Economic and Social History Review (1982) 19, pp. 63-82. Kumar systematically shows how, with rare exceptions, across fields, deserving Indian candidates are denied positions and salaries on equal terms with European counterparts, despite attaining comparable scholastic degrees. 
Indian Science Congress in Lucknow (1920) regarding the peopling of the scientific services,

Among the occupiers of these posts, there have been many distinguished European savants of great name and fame. I do not for a moment wish to minimise their achievements. The credit of their work, however, belongs to their own native countries, and the results of their experience are enjoyed by their own countrymen. I shall try to make my point a bit clearer. The Indian lives and moves and has his being in the midst of his own people; the European, somehow or other, lives in a world apart, and from his exalted position of aloofness and isolation fails to inspire those who may happen to come into contact with him. ${ }^{32}$

As reflected in the statement above, the professionalization of natural history in British India, therefore, had largely fallen to a group of European expatriates whose working life was in major part or wholly devoted to work in India, a group which one of us (Mathew) has denominated 'translocates'. ${ }^{33}$ They were administrators (like Hodgson), doctors (like Day and Jerdon), military officers or occasionally clerics. Importantly, they saw themselves as both European (in the main, British) and Indian. Thus, while recognizing the justifiable criticism in Ray's position in part, it is also true that the fact of long-term domicile in India in many ways would throw 'translocates' into active contest with workers doing natural history in the metropole, particularly London. For example, the Bombay Natural History Society, which was founded in 1886 by eight individuals (six Britons and two Indians) and in short order produced a journal, carried trenchant accounts by local naturalists/sport hunters of tomes of natural history written by zoologists working in the British Museum of Natural History (now the Natural History Museum) in London who had never been to India. ${ }^{34}$

\section{Knowledge production: power, coloniality and geopolitics}

We have already seen how 'native Indian scientists' fared in the racial hierarchy of colonial scientific institutions: perfectly deserving trained native Indian workers were denied parity in employment and remuneration with European workers. The same extended in the nineteenth century to universities, where, despite their existence from the late 1850s (Calcutta, Madras and Bombay), they were little more than examining centres, with no

32 P.C. Ray, 'Dawn of science in India' (1920), in The Shaping of India Science: Indian Science Congress Association Presidential Addresses, vol. 1: 1914-1947, Hyderabad, Universities Press (India) Private Limited, 2003, pp. 82-93.

33 Mathew adopts the term 'translocate', if in somewhat modified form, from classical cytogenetics, where during crossover in the first meiotic phase of reproductive cell division there is exchange of chromosomal material in a process known as translocation. The result is an altered chromosome, possessed of a significantly different character from its original form. See John Mathew, 'To fashion a fauna for British India', PhD thesis, Harvard University, 2011. The translocate is a subset of the expatriate, but assumes an inflection of specialization, where his or her action is actively directed towards the accrual of information and where he/she mediates the flow of knowledge between systems that at first glance may appear to be incommensurable.

34 See, for instance, anonymous, 'Review of G. Boulenger, Reptiles and Batrachia, The Fauna of British India, including Ceylon and Burma' (London: Taylor and Francis, 1890), Journal of the Bombay Natural History Society (1891) 6, pp. 100-104. 
attention afforded to original research, owing to negligence on the part of the British administration. If anything, by the turn of the century, the overseeing of science in India was administratively given over to two bodies, one in Britain, the Indian Advisory Committee (IAC) of the Royal Society, and the other in India, the Board of Scientific Advice (BSA), falling under the remit of its government. The generating impulse for both bodies had four different but complementing tendencies in imperial and colonial policy: (1) the traditional use of science by Britons to 'explore and exploit the geography and natural resources of the colonies in general and the Indian subcontinent in particular for the benefit of British commerce', where natural history was a major area of investigation; (2) the expansion of the civil service in India, many of whom were medical men; (3) the effects of doctrines of imperialism predicated upon optimistic liberalization at the turn of the twentieth century; and (4) the immediacy of problems that potentially had remedies in science such as famine, epidemics, pest infestation, poor sanitation and inferior agricultural yields. ${ }^{35}$

With solutions, however, still not immediately at hand, the Royal Society was consulted (given its own standing with the British government) and the IAC came into being. The famines of 1898 and 1900 saw the then viceroy, Lord Curzon, turn to the Royal Society for help. But he also created the BSA, to whom the various scientific branches would have to turn and where practical scientific research was both desideratum and dictate. However, the BSA was still obliged to send its programme of work to the Royal Society, where the pursuit of knowledge in itself was an end. This naturally led to a conflict with the BSA, where utilitarian goals were paramount, even though the vast majority of members of the IAC were old India hands. The society itself soon became condescending and patronizing, which left the BSA irate. While many suggestions from the society via the IAC were adopted by the BSA, unsolicited points of criticism only serve to fan the flames, to the extent that the BSA went so far as to suggest that the IAC was deliberately seeking to suppress new discoveries emerging from India, on the probable assumption that scientists there were incapable of making them.

The feeling was not unfounded, given that the Royal Society believed that scientists in India should concentrate on problems in that country while concerns of a more fundamental nature were best left to Europe. Affairs came to a boil in 1910 when the Geological Survey of India (GSI), under the directorship of Thomas Holland (18681947), ${ }^{36}$ was roundly criticized by the Royal Society for not taking seriously its recommendations, with the resultant report of the survey being sporadic and fitful. Holland responded with a series of charges of his own; there were too many to recapitulate here, but significantly he made three suggestions: (1) that the size of the board of the IAC be reduced for purposes of administrative efficiency; (2) that the IAC be expanded for better coverage or else dissolved; or (3) that the system be revised, so that the IAC should not overreach its mandate, and should simply provide its advice when such

35 Roy Macleod, 'Scientific advice for British India: imperial perceptions and administrative goals, 18981923', Modern Asian Studies (1975) 9, pp. 343-384, 346.

36 Ironically, Holland himself had leapfrogged an Indian, P.N. Bose, to the directorship of the GSI in 1903, leading to the latter's precipitate retirement. See Kumar, op. cit. (29), p. 75. 
was sought. The Holland Memorandum, or so it was called, of 1909, caused consternation back in London, but there was increasing appreciation of the fact that local knowledge was key, particularly in cases of problems of economic science, even if the stated reason was on account of dealing with 'the habits and prejudices of an ignorant and suspicious population, and ... the limitations of the subordinate staff with which [the] officers ha[d] to work' ${ }^{37}$ Ultimately there were mutual apologies and the BSA succeeded in obtaining independence from the Royal Society's watch. While there was a slackening in terms of reform under the BSA subsequently, the upheaval ultimately proved beneficial for the India of the early 1910s, with the creation of the Indian Research Fund Association (later the Indian Council for Medical Research - ICMR) and the Indian Science Congress, ${ }^{38}$ to which attention has earlier been drawn.

In the case of China, the power relations of knowledge production were even more complex because of the shifting configuration of science, colonalities, national politics and global geopolitics. In many ways, science in Republican China was an international or transnational affair, and consequently care must be taken to avoid such easy binary categories as Chinese/foreign. Major scientific institutions, organizations and communities were often international in their financing and personnel. Furthermore, on many issues, not all Chinese lined up on one side and foreigners on the other. Besides, foreign scientists in China came in different sizes, shapes and stripes. Some stayed in China for decades and others only briefly. Some taught at Chinese universities (for example Amadeus Grabau) or worked for Chinese government agencies (for example Johan Gunnar Andersson); some joined missionary colleges (for example Nathaniel Gist Gee and Alice Boring) or were themselves missionaries (for example Emile Licent and Teilhard de Chardin) and others found positions in institutes sponsored by foreign philanthropists (for example the Peking Union Medical College or PUMC, financed by the Rockefeller Foundation, and the Henry Lester Institute, a British establishment in Shanghai). Some were members of full-scale scientific expeditions (for example the Central Asiatic Expeditions of the American Museum of Natural History) and others continued the nineteenth-century tradition of sportsmen-naturalists (for example Arthur de Carle Sowerby). Of course, there were also Japanese scientists, who were active in Taiwan, Korea, Manchuria and Inner Mongolia and who staffed the Shanghai Institute of Natural Sciences, a controversial establishment, which many Chinese scientists considered a beachhead of Japanese scientific imperialism. ${ }^{39}$

In addition to the formal institutions mentioned above, foreign scientists in China formed a number of active science societies. As they were of different backgrounds, the societies varied in important aspects. Established in Shanghai in the mid-nineteenth century, the North China Branch of the Royal Asiatic Society remained active. In the 1920 s and 1930s, another gentlemen's society of a similar nature, called the China Society of Science and Art, came on the scene, and it published a noted magazine, the

37 Nature (21 February 1907) 75, p. 403, quoted in MacLeod, op. cit. (35), p. 370.

38 MacLeod, op. cit. (35), p. 372.

39 Zhang Jian, Kexue shetuan zai Zhongguo de mingyun, Jinan: Shandong jiaoyu chubanshe, 2006; Liang Bo, Jishu yu diguo zhuyi yanjiu, Jinan: Shandong jiaoyu chubanshe, 2006; Han Jianping, Riwei shiqi de zhimindi keyan jigou: lishi yu wenxian, Jinan: Shandong jiaoyu chubanshe, 2006. 
China Journal of Science and Art. Sowerby, who edited the journal, and others like him carried on the torch of nineteenth-century European naturalists in China. By this time, such societies were more or less open to Chinese gentlemen of high social standing, particularly the ones who had received Western education and were at ease in Western company. This was certainly the case with societies of an academic background, for example the Peking Society of Natural History. ${ }^{40}$

There was a vibrant international scientific community in Beijing in the 1920s and 1930s that consisted of Chinese and Western geologists and biologists who congregated in the Peking Society of Natural History. The society held regular meetings and published a journal, the Bulletin of the Peking Society of Natural History. A participant in a meeting of the society would find him- or herself in the same room as leading Chinese scientists, foreign scientists working in China, members of international scientific expeditions, and visiting foreign scientists. This international scientific community in Beijing was far from being a club of amateurs on the periphery of modern science. Many active members or visitors were scholars of international renown, such as the geologist Amadeus Grabau, the palaeoanthropologist Davidson Black and the geographer Sven Hedin. The Peking Union Medical College was well equipped and its staff was full of researchers decorated with degrees from top universities in the world. Many Chinese scientists, such as the geologist Weng Wenhao, had equally solid credentials. The high-profile scientific expeditions brought international attention to Beijing; the exploits of Roy Chapman Andrews's expeditions and the discovery of Peking Man in 1929 were scientific sensations. Indeed, China was one of the hotspots of archaeology, palaeontology, palaeoanthropology, geology, natural history and medical research in the world at the time. ${ }^{41}$

This international scientific community demonstrated a fair degree of scientific internationalism or cosmopolitanism, though it also exhibited connections to civilizing mission and scientific philanthropy. Friendships among the main Chinese and Western members further solidified the community. Nevertheless, this rosy picture ignores the broader context and certain tensions beneath the surface. Imperialism, nationalism, international politics and racism never entirely disappeared. Some Westerners could not shed their prejudices, and most Chinese intellectuals, including scientists, were nationalists who resented Western and Japanese imperialism. The binary of imperialism and nationalism, however, does not capture the complex views of the Chinese scientists, who shared important commonalities with their foreign colleagues. Elite Chinese scientists had studied the very same topics and received the same training at the very same universities in Europe and the United States as their foreign colleagues. They Chinese as well as Western - believed in the universal validity of science. They considered themselves members of a scientific community similar to the Republic of Letters, where

40 Grace Yen Shen, 'Periodical space: language and the creation of the scientific community in Republican China', in Jing Tsu and Benjamin Elman (eds.), Science and Technology in Modern China, 1880s-1940s, Leiden: Brill, 2013, pp. 269-296.

41 Luo Guihuan, Zhonguo xibei kexue kaochatuan zonglun, Beijing: Zhongguo kexue jishu chubanshe, 2009; Sigrid Schmalzer, The People's Peking Man: Popular Science and Human Identity in TwentiethCentury China, Chicago: The University of Chicago Press, 2008, pp. 17-53. 
truths ought to be determined by reason, evidence, scientific method and objective inquiry.

Science, modernity and the nation were powerful ideas that many Western and nonWestern scientists shared. But precisely because they shared these ideas, they sometimes ended up facing off each other. The tensions were elements of the global geopolitics of knowledge production. With the establishment of major research institutes and the multiplication of their ranks, Chinese scientists grew more confident. The late 1920s may be seen as a key moment because, as noted earlier, major research institutes, such as Academia Sinica, the Peiping Academe and the Fan Memorial Institute of Biology, came into existence. About this time, Chinese archaeologists began their own large excavation projects and steadily elbowed foreign teams out of the way. A series of major controversies over antiquities and fossils between Chinese intellectuals and Western explorers and scientists - including the blow-up involving the Asiatic expeditions of the American Museum of Natural History led by Roy Chapman Andrews, whose arrogance irked the Chinese - helped to introduce the policy and laws regulating foreign expeditions in China. The new rules included such measures as that any foreign expedition must have a Chinese co-director and some Chinese members on the scientific staff, Chinese scientific institutes should have the first pick of the collected fossils and antiquities and only duplicates may be shipped away, and so on. ${ }^{42}$

The ground was gradually shifting. Not that there were not power differentials - there were. But they were not fixed or necessarily stable, depending on the particular circumstances. New nation states, such as China, were trying to assert their sovereignty over their territories and their nation's nature. In 1930, China passed a comprehensive antiquities law that also covered fossils, and Academia Sinica was charged in 1934 with drafting a similar policy regarding zoological and botanical specimens. The main purpose of these regulations was to define the ownership of and control the traffic in these objects of science. In doing so, they actively participated in reconfiguring the geospatial politics of knowledge production and circulation of material objects in science. ${ }^{43}$

Under modern nationalism, nature was incorporated into the geobody of the nation. ${ }^{44}$ Animals and plants were not simply objects of nature; they were also part of the nation. It would no longer be acceptable for foreigners to come, collect and remove them freely from the nation's body. Moreover, in natural history, taxonomy and systematics depended heavily on collections of specimens. Kew Gardens was the mecca of plant taxonomy because of its gigantic collections of specimens from all over the world, including China, and those contained numerous type specimens. In this sense, the herbarium of

42 Fa-ti Fan, 'Circulating material objects: the international controversy over antiquities and fossils in twentieth-century China', in Bernard Lightman, Gordon McOuat and Larry Stewart (eds.), The Circulation of Knowledge between Britain, India and China, Leiden: Brill, 2013, pp. 209-244.

43 Fan, op. cit. (42).

44 Tongchai Winichakul, Siam Mapped: A History of the Geo-body of a Nation, Honolulu: University of Hawaii, 1997; Fa-ti Fan, 'Nature and nation in Chinese political thought: the national essence circle in early twentieth-century China', in Lorraine Daston and Fernando Vidal (eds.), The Moral Authority of Nature, Chicago: The University of Chicago Press, 2004, pp. 409-437. Shen, op. cit. (7). See also Sean Hsiang-lin Lei, Neither Donkey nor Horse: Medicine in the Struggle over China's Modernity, Chicago: The University of Chicago Press, 2014. 
Kew Gardens was part of the imperial archive of the British Empire and beyond. Indeed, the herbarium was literally an archive - specimens were identified, labelled, classified and filed, and strata of history and knowledge accumulated. The imperial archive of specimens testified to the power and reach of an empire. It also translated into power in science. Large collections of specimens from important regions placed one in a position to speak with authority about the natural world - the distribution, variation, identities and relationships of particular plants or florae. Again, the power relations were not static or necessarily stable, but were dynamic, contingent, shifting and contextual. Scientists in India and China could mobilize their site-based knowledge and expertise to challenge authority based on such archives. But still there were structures and hierarchies in the world of science. Not surprisingly, Chinese scientists felt that even in matters about the flora and fauna of China - part of the geobody of their own nation - they still got the short end of the stick. It was, in part, for this reason that they wanted to build their collections of specimens - that is, their own archives - documenting the flora and fauna of China.

\section{Conclusion}

What have we learned from comparing biological surveys in India and China? There were obvious similarities and differences. Two very large countries, with much left unexplored, attracted broad scientific interest in their flora and fauna from the early modern period; the interest intensified in the nineteenth century because of increasing accessibility to their interiors. The two countries had gone on different paths, however. India became part of the British Empire and much of the research on its flora, fauna and natural environment was under the aegis of the colonial state, and, as it happens, most of the scientists active in botanical and zoological surveys were translocates rather than native Indians. Although China often found itself under the thumb of foreign imperial powers, it never became a formal colony of any of them. Chinese scientists of the early twentieth century were eager to study the flora, fauna and natural environment of China, in cooperation as well in competition with foreign scientists.

In both cases, the scientists recognized the importance of biological surveys to state building, whether it was a colonial state or a nation state. The idea was part of the raison d'être of the modern state, a political ideology and institution that must render eligible its constituents and resources - its population, nature, territory and production. Surveying the flora and fauna was part of the enterprise. Nevertheless, the enterprise also derived from the historical lineage and ambition of natural history itself - its desire and effort to discover, collect, describe, classify, preserve and appreciate objects of nature, whether it was understood to be God's creation or, later, the nation's nature. The Chinese scientists quickly adopted botanical and zoological surveys as part of the project of modernization and nation-state building, but they also tapped into the aesthetic sentiment and historical tradition of topophilia. In India, major scientists in biological surveys were translocates; they were not nationalists as such. Yet many translocates also developed strong feelings about the place and land in which they had spent most or all of 
their lives and careers. They might have held ambivalent views and feelings about India, but they also formed an identity and sense of pride connected to the land and its flora and fauna. They were confident and jealous of their accomplishments and they spoke to colleagues in the metropole from a position of knowledge and authority. Instead of centre and periphery, it was rather a network of science with nodal points of varying degrees of traffic and relevance. In some ways, India was a scientific 'centre' in its own right.

One can perhaps say the same thing about China, though the situation was quite different. In the 1920s and 1930s, Beijing was a centre of international science; Chinese scientists mingled with colleagues from Europe, Japan and the United States. International scientific expeditions gathered and used the city and its vibrant scientific community as a base. Up-to-date research and educational institutes were established. The international character of science similarly manifested itself in Shanghai, Tianjin and Manchuria. Chinese scientists simultaneously benefited from the presence of international scientific interests and were keenly aware of the power relations inherent in the international scientific community. Whether it was India or China, it seemed that one condition for the ability to speak - to make one's voice heard - was to have research institutes, a steady supply of competent scientists, active science societies, journals, zoological and botanical gardens, biological surveys and, not least, well-stocked herbaria and museums. Good collections of specimens fortified one's scientific authority. Good collections of specimens also served as archives of the nation's nature or of the colonial land.

Arguably, despite their differences, China and India shared important similarities in the global hierarchy of knowledge production and in the coloniality of power relations. Scientists in India and China did not occupy obvious positions of power and prominence, but they had some strategic advantages over their colleagues in the presumed centres. This complexity permeated the field sciences, including natural history and the more systematic biological surveys. This complexity also represented an important aspect of the global history of science, one that still bears poignancy and resonance in the contemporary world. 